\title{
Social Contact, Academic Satisfaction, COVID-19 Knowledge, and Subjective Well-being Among Students at Turkish Universities: a Nine-University Sample
}

\author{
Gülsen Erden ${ }^{1}$ (1) Asil Ali Özdoğru² (i) Sami Çoksan ${ }^{3,4}$ (1) \\ Hale Ögel-Balaban ${ }^{5}$ (D) Yakup Azak $^{6}$ (1) . ilkiz Altınoğlu-Dikmeer ${ }^{7}$ (1) .

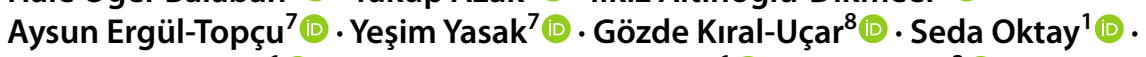 \\ Pelin Karaca-Dinç ${ }^{1}$ - Ezgi Didem Merdan-Yıldız ${ }^{1}$. Selen Eltan ${ }^{3}$ (i) . \\ Güler Beril Kumpasoğlu ${ }^{3} \oplus$. Gülsen Baytemir ${ }^{9}$
}

Received: 19 May 2021 / Accepted: 12 November 2021 / Published online: 2 December 2021

(C) The International Society for Quality-of-Life Studies (ISQOLS) and Springer Nature B.V. 2021

\begin{abstract}
Adverse effects of COVID-19 are seen not only on the physical health of infected individuals but also on their subjective well-being. Sudden changes in social lives, lockdowns, and shifts towards online education have had a negative impact on many people, especially university students. As part of an international study, the current study focused on the well-being of students at Turkish universities in relation to social contact, academic satisfaction, and COVID-19 knowledge. A total of 7363 students from nine universities $(86.6 \%$ from state universities, $71.04 \%$ female, and $73.52 \%$ at bachelor's level) participated in an online survey. Results revealed that females had lower levels of subjective well-being and academic satisfaction. According to a mediation model in the study, the relationship between social contact and well-being was mediated by academic satisfaction and COVID-19 knowledge. Our findings can guide future researchers, mental health professionals, universities, and policymakers to understand and improve subjective well-being of university students.
\end{abstract}

Keywords Subjective well-being · Social contact · Academic satisfaction · COVID19. University students

An earlier version of this study was presented in 2020 at the 56th National Congress of Psychiatry in Turkey.

Sami Çoksan

scoksan@metu.edu.tr

Extended author information available on the last page of the article 
COVID-19 is one of the pandemics that have affected people all over the world, changed the natural course of life, and had significant physical, psychological, and social effects. Throughout history, humanity has experienced many pandemics such as cholera, plague, SARS, and swine flu. Some of them affected large masses for a short time, while some others have relapsed repeatedly over the centuries (Colwell, 1996; Dandagi \& Byahatti, 2011; Neerinckx et al., 2010; Stenseth et al., 2008). The difference of COVID-19 from the other pandemics is that it caused a severe death toll compared to other pandemics within a short period of time, which is 1 year since its emergence (WHO, 2020); appearing almost all over the world during this period (Islam et al., 2020), and along with intense quarantine and restriction processes, it has led to radical changes in many areas of people's lives such as work, school, family, and social life (Arslan et al., 2020; Chen \& Yuan, 2020; Chen et al., 2020a, b; Islam et al., 2020). During the COVID-19 pandemic process, quarantines were implemented in many countries and restrictions were imposed on public spaces (Arslan et al., 2020; Chen \& Yuan, 2020; Chen et al., 2020a, b; Islam et al., 2020).

During COVID-19 period, the education system moved to online platforms in many parts of the world including Turkey; therefore, students, teachers, and families had to adjust to this change rapidly. University students were one of the most affected groups by this drastic arrangement (Durak et al., 2020; Ertuğ, 2020). There has been a rapid transition from face-to-face education to online education. However, the online education infrastructure of universities was insufficient for this change (Durak et al., 2020; Ertuğ, 2020) and internet access was not available for all university students (Aboagye et al., 2020; Adnan \& Anwar, 2020; Shek, 2021). In addition, the closure of communal areas such as schools and libraries has highlighted inequalities in terms of Internet access (Beaunoyer et al., 2020). With the closure of the universities and dormitories, the students moved away from the campus environment, and had to change their accommodation arrangements. Due to the closure of the universities, students had difficulties in adapting to attend online courses, mostly from their homes (Duman, 2020), they experienced anxiety about academic performance, and their social interactions decreased (Son et al., 2020).

As a result, the COVID-19 pandemic has had a substantial impact on university students' life. Many of the students were not familiar with distance learning. After the pandemic, a new concept, "online instruction" has become a part of their daily routines and affected their subjective well-being. During the COVID-19 outbreak, most students reported increased anxiety, stress, and depression symptoms (Islam et al., 2020; Wang \& Zhao, 2020, Ye et al., 2020). Moreover, the students experienced problems with loneliness and boredom (Yehudai et al., 2020). It is observed that the students' complaints such as depression, anxiety, stress, and loneliness increased during the pandemic and these complaints affected their well-being.

Studies conducted during the COVID-19 pandemic indicate that many biological, psychological, and socioeconomic factors affect the well-being of university students. Well-being is defined as "the fact that the person subjectively believes his or her life is desirable, pleasant, and good" (Diener, 2009, p. 1). According to Diener et al. (1997), subjective well-being indicates people's interpretation about their lives and it includes three components which are thoughts (cognitive) and intensity of desirable and undesirable emotions (positive and negative affect). 
Arthaud-Day et al. (2005) reinvested that these three are distinguishable parts of subjective well-being from each other theoretically. Cognitive well-being is the level of satisfaction about individual's own life; however, positive affect indicates pleasant experiences itself in people's lives (Arthaud-Day et al., 2005; Crooker \& Near, 1998; Horley \& Little, 1985). Negative affect is also the unpleasant experiences; however, it is not the opposite of the positive affect, but they are separate experiences (Diener et al., 1997). Orben and Przybylski (2019) used scales that evaluate mental health and suicidal thoughts, depression, happiness, selfesteem concepts, and feelings while evaluating adolescents' well-being. Metler and Busseri (2017), on the other hand, discussed negative and positive emotions and life satisfaction while evaluating subjective well-being. Gassman-Pines et al. (2020) measured well-being by assessing negative mood (e.g., angry, anxious, depressed) and sleep quality. In our study, well-being was measured by evaluating concepts such as positive (e.g., happy, calm, peaceful) and negative affect (e.g., depressed, sad, bored, anxious, frustrated, lonely, isolated), enjoyment of life, and sleep quality.

Several studies reported the negative impact of COVID-19 pandemic on university students' well-being. The pandemic had negative effects on mental health and movement behaviors of UK university students (Savage et al., 2020), emotional symptoms and happiness of Malaysian university students (Wan Mohd Yunus et al., 2021), and depression, anxiety, and stress levels of Lebanese (Fawaz \& Samaha, 2021) and Bangladeshi university students (Sifat, 2020). Unpredictability of the future/career, self-isolation, financial instability (Li et al., 2021), perceived low social status, and academically negative learning experiences (Dodd et al., 2021) were examined as factors that weaken subjective well-being. In another study, the stressors associated with the psychological distress of university students were directed towards the academic future, task overload, worsening of interpersonal conflicts, limitations in social contact, and illness (Padrón et al., 2021). Conflicts between family roles and academic roles were taken as factors that negatively affect subjective well-being (Badri \& Yunus, 2021).

As mentioned above, the COVID-19 pandemic has led to significant changes in the lives of university students. Students switched to the online education process and moved away from campuses and peers due to certain restrictions. In other words, this situation caused students to be away from their persons of social contact. Social contact, which is one of the factors affecting students' subjective well-being, can be an important predictor of resilience after traumatic experiences and disasters (Oppedal et al., 2018; Wang \& Xu, 2017). Indeed, social support also appears to be important for positive adaptation to the COVID-19 process (Saltzman et al., 2020). In a study conducted with university students, two different forms of social support (i.e., aid-related and appreciation-related social support) had direct and indirect effects on subjective well-being (Gençöz et al., 2004). More social support and more connection with teammates during the pandemic, reported by the student athletes, were associated with better well-being (Graupensperger et al., 2020). In addition to the concerns of COVID-19, distancing from social networks, physical isolation, lack of interaction, and emotional support were found to have negative effects on students' mental health (Elmer et al., 2020). Moving away from the university and 
staying away from friends and partners are among the factors that increase the anxiety levels of university students (Villani et al., 2021).

For university students, academic satisfaction can be an important variable in terms of mental health as well as social contact. In the relevant literature, academic satisfaction is one of the factors that is related with the well-being of university students (Franzen et al., 2021; Gopalan et al., 2019; Jan, 2015; Sim \& Lui, 2020; Tomyn, 2019). Lebanese university students' satisfaction with e-learning during the pandemic had a negative relationship with their levels of depression, anxiety, and stress (Fawaz \& Samaha, 2021). Gopalan et al. (2019) indicated a positive relationship between the self-efficacy of students and their academic satisfaction. Another study with medical students indicated that academic satisfaction is positively correlated with subjective well-being and negatively correlated with anxiety and depression (Franzen et al., 2021). During the quarantine that emerged with COVID-19, university students had to adapt to increased homework loads and long school hours spent in front of the computer (Hagedorn et al., 2021). Therefore, school achievement and academic satisfaction emerged as an important condition affecting the psychological health of university students. Studies on the COVID-19 experiences also revealed a significant relationship between students' academic satisfaction and subjective well-being (Hassan et al., 2021; Tran et al., 2021). It is indicated that academic satisfaction is correlated with positive perceptions of students about themselves (Hassan et al., 2021). Tran and his colleagues (2021) found that academic satisfaction is positively associated with well-being of students in COVID-19 pandemic.

Academic satisfaction is also associated with social contact (Gopalan et al., 2019; Jung et al., 2002). Although the authors did not come across any study specifically on the relation between social contact and academic satisfaction during the COVID-19 pandemic, in some pre-pandemic studies about computer-mediated education, social contact predicted academic satisfaction (Gunawardena \& Zittle, 1997; Kanuka \& Anderson, 1998). According to Jung and her colleagues (2002), social contact, especially among students, is associated with satisfaction for learning. Furthermore, contact with the institution and academic staff leads to academic satisfaction for students (Gopalan et al., 2019). As well as academic satisfaction, life satisfaction is also related to social contact for students (Coffman \& Gilligan, 2002; Diener \& Fujita, 1995). These studies show that social contact is particularly important for satisfaction with learning and academics in university students.

COVID-19 recently entered the lives of the people and brought many unknowns, and many new terminologies were added to people's vocabulary. Many people had the urge to get as much information as possible about the disease. Many people try to get information about this new disease from specific sources such as TV news, official websites of institutions, or social media. Although studies indicate that information on COVID-19 is mostly obtained from online platforms (Ko et al., 2020; Wang \& Zhao, 2020), students rely on information mostly from public health institutions (The Healthy Minds Network \& American College Health Association, 2020). A variety of information that people are exposed to affects people's wellbeing in different ways. Among a few studies on this subject, controversial results were revealed. For individuals over the age of 18, social media use and getting 
information about COVID-19 were found to be associated with elevated negative affect (Lades et al., 2020). On the contrary, Cox and Brewster (2020) stated that accessing information about any subject by any means has a positive impact on people. In their study, digital access to information specifically about pandemic positively affected the subjective well-being of university students.

The subjective well-being of Turkish university students was also found to be negatively influenced by the pandemic. Students reported fear of their relatives getting ill by the coronavirus and their anxiety was positively correlated with their information consumption from the media (Akdeniz et al., 2020). In a study with medical faculty students, more than half reported feeling mentally unwell (Aker \& Midik, 2020). In another study, $64.6 \%$ of students reported symptomatic signs of depression, $48.6 \%$ anxiety, $45.2 \%$ stress, and $34.5 \%$ post-traumatic stress disorder (Çam et al., 2021). COVID-19 related distress (Ay et al., 2021) and depression (Karaşar \& Canl1, 2020) were found to be higher among women. On the other hand, older age and resilience (Ay et al., 2021; Karaşar \& Canl1, 2020) and meaning in life (Arslan et al., 2020) were found to promote higher levels of well-being.

Although there are relevant studies in the literature on the relationship between social contact and subjective well-being (Elmer et al., 2020; Graupensperger et al., 2020; Villani et al., 2021), upon our knowledge, the relationship between academic satisfaction and information about COVID-19 has not been published yet. The level of knowledge about the virus and the disease may well be related to the level of anxiety about the future and the satisfaction on academic status, which may have an impact on subjective well-being in the COVID-19 pandemic. In this study, the relationship between social contact, academic satisfaction, COVID-19 knowledge, and well-being among Turkish university students will be examined. The aim of the study is to examine the subjective well-being of students in relation to demographic variables and their self-reported levels of social contact, academic satisfaction, and COVID-19 knowledge.

We proposed that social contact would predict well-being through serial two mediators which are academic satisfaction and COVID-19 knowledge, respectively. Thus, we aimed to reveal the mediating role of academic satisfaction and COVID-19 knowledge in the association between social contact with friends or family, and subjective well-being during the COVID-19 period among university students in Turkey. The model also offered us the opportunity to interpret the impact of academic satisfaction on well-being; hereby, we discussed the possible effects of academic satisfaction of university students, one of the groups most affected by the pandemic.

\section{Method}

\section{Sample}

Between April and June 2020, 7363 students from nine universities in Turkey participated in the study. Eighty-seven percent of the students $(n=6382)$ were from six public universities and the remaining $13 \%$ of the students $(n=981)$ were from 
three foundation universities. They were recruited through convenience sampling. The mean age of participants was $23.48(S D=6.07, R=17-75)$. Most of them were female $(71.04 \%)$ and at bachelor's level $(73.52 \%)$. Their demographic characteristics are provided in Table 1.

The majority of the participants $(44.18 \%)$ were living with their parents before the COVID-19 outbreak and the number of participants living with their parents had increased during the COVID-19 outbreak $(82.60 \%)$. More than half of the participants $(64.21 \%)$ reported having sufficient resources to cover their monthly living expenses before COVID-19, but this ratio had decreased during the COVID-19 outbreak (52.18\%). Tuition fees of half of the participants were covered by the state $(n=3668,49.82 \%)$. Further information on the financial and residential conditions of the participants are presented in Table 2.

Most of the participants reported that they did not have any chronic illnesses. The number of COVID-19 cases confirmed by a test or healthcare professional

Table 1 Summary characteristics of the study population $(N=7363)$

\begin{tabular}{|c|c|c|c|c|}
\hline Information & Characteristics & Category & $N$ & $(\%)$ \\
\hline \multirow[t]{10}{*}{ Sociodemographic information } & \multirow[t]{3}{*}{ Gender } & Male & 2092 & 28.41 \\
\hline & & Female & 5231 & 71.04 \\
\hline & & Other & 40 & 0.54 \\
\hline & \multirow[t]{2}{*}{ Country of birth } & Turkey & 7038 & 95.59 \\
\hline & & Other & 325 & 4.41 \\
\hline & \multirow[t]{2}{*}{ Citizenship } & Citizen & 7130 & 96.84 \\
\hline & & Foreign & 233 & 3.16 \\
\hline & \multirow[t]{3}{*}{ Relationship status } & Yes & 2783 & 37.80 \\
\hline & & No, single & 4062 & 55.17 \\
\hline & & Complicated & 518 & 7.04 \\
\hline \multirow[t]{15}{*}{ Study-related information } & \multirow[t]{2}{*}{ First-year student } & Yes & 2013 & 27,3 \\
\hline & & No & 5350 & 72,7 \\
\hline & \multirow[t]{8}{*}{ Study fields } & Education and language & 765 & 10.39 \\
\hline & & Art & 96 & 1,30 \\
\hline & & Social sciences & 1145 & 15.55 \\
\hline & & Humanities & 1023 & 13.89 \\
\hline & & Engineering and sciences & 1323 & 17.97 \\
\hline & & Health sciences & 1456 & 19.77 \\
\hline & & Services & 61 & 0.83 \\
\hline & & Two or more fields & 1194 & 16.22 \\
\hline & \multirow[t]{5}{*}{ Educational program } & Two-year degree & 868 & 11.79 \\
\hline & & Bachelor & 5414 & 73.53 \\
\hline & & Master & 677 & 9.19 \\
\hline & & Ph.D. & 390 & 5.30 \\
\hline & & Other & 12 & 0.16 \\
\hline
\end{tabular}


Table 2 Financial and residential conditions before and during COVID-19 outbreak $(N=7363)$

\begin{tabular}{llll}
\hline & & $n$ & $(\%)$ \\
\hline Financial resources to cover monthly costs & & \\
Before COVID-19 & Sufficient & 4728 & 64.21 \\
& Moderately sufficient & 1394 & 18.93 \\
& Insufficient & 1241 & 16.85 \\
During COVID-19 & Sufficient & 3842 & 52.18 \\
& Moderately sufficient & 1491 & 20.25 \\
& Insufficient & 2030 & 27.57 \\
Residential preferences & & & \\
Before COVID-19 & With parents & 3253 & 44.18 \\
& Student hall & 1723 & 23.40 \\
& Accommodation with others & 919 & 12.48 \\
& Living alone & 597 & 8.11 \\
& Other & 871 & 11.83 \\
During COVID-19 & With parents & 6082 & 82.60 \\
& Student hall & 97 & 1.32 \\
& Accommodation with others & 249 & 3.38 \\
& Living alone & 334 & 4.54 \\
& Other & 601 & 8.16 \\
\hline
\end{tabular}

Table 3 Health and COVID-19 symptoms related information

\begin{tabular}{|c|c|c|c|}
\hline & & $n$ & $(\%)$ \\
\hline \multirow[t]{2}{*}{ Chronic diseases } & Yes & 1128 & 15.32 \\
\hline & No & 6235 & 84.68 \\
\hline \multirow[t]{3}{*}{ Having COVID-19 symptoms } & Yes & 1662 & 22.57 \\
\hline & No & 4806 & 65.27 \\
\hline & Unsure & 895 & 12.16 \\
\hline \multirow[t]{3}{*}{ Hiding symptoms from others } & Yes & 484 & 18.9 \\
\hline & No & 1869 & 73.1 \\
\hline & Unsure & 204 & 8 \\
\hline \multirow[t]{4}{*}{ Having COVID-19 currently } & Yes, confirmed by test & 20 & 0.27 \\
\hline & Yes, health care provider told & 45 & 0.61 \\
\hline & Yes, I think, but not confirmed & 296 & 4.02 \\
\hline & No & 7002 & 95.10 \\
\hline
\end{tabular}

was $22.57 \%$. Detailed information about health-related information is presented in Table 3.

\section{Measurements}

The COVID-19 International Student Well-being Study (C19 ISWS) questionnaire was used in the present study. The questionnaire was developed by the Centre for 
Population, Family and Health Research Group at the University of Antwerp and the Health and Demographic Research Group from Ghent University. It was constructed based on the social stress model and the literature on the effect of quarantine on well-being, and the current study was part of an international research project (Van de Velde et al., 2021). The items were adapted from previously validated survey instruments or developed by the research groups.

The questionnaire was translated into Turkish through a committee approach. Two researchers who were partners of the C19 ISWS Consortium at two Turkish universities (whose data were not included in the present study) translated the questionnaire independently from English to Turkish. They compared their translations and created a draft. Then, the draft was shared with the other Turkish partners, who are the authors of the present paper. The disagreements regarding the translation were solved and the final version was created. Additionally, some new items on students' activities were added.

The original C19 ISWS Questionnaire includes 7 modules: (1) sociodemographic information, (2) study-related information, (3) before and during the COVID-19 outbreak, (4) COVID-19 diagnosis, symptoms and perceived worries, (5) stressors, informal support, and mental well-being, (6) student-specific questions and concerns, and (7) COVID-19 knowledge and information. Below, only the information about the scales included in the scope of this research is presented.

\section{Sociodemographic and Study-Related Information Form}

The sociodemographic form included 8 items on sex, age, relationship status, and parental education level. Study-related information form, on the other hand, consisted of 7 items on higher education institution, study program, field of study, being a first-year student or not, and how the tuition is covered.

\section{Daily Conditions Before and During COVID-19 Outbreak}

This form included 10 items that compared participants' conditions before and after the COVID-19 outbreak. The form covered participants' financial resources (e.g., I had sufficient financial resources to cover my monthly costs) and residential preferences before and after the COVID-19 outbreak (e.g., Where did you mainly live -excluding weekends and holidays-?). For the questions on the condition before the COVID-19 outbreak, participants were asked to think about the average condition during the month before to the implementation of the first COVID-19 measure, and for the questions on the situation after the COVID-19 outbreak to consider the average condition during the week prior to the study. 


\section{COVID-19 Symptoms and Health}

This form consisted of items on participants' chronic diseases such as heart disease and diabetes. In addition, questions about whether the participants were diagnosed with COVID-19, whether they had symptoms of the disease, and whether they hid these symptoms from others, if any, were also included in this form

\section{Subjective Well-being}

Subjective well-being scale consisted of 14 items which participants rated their subjective well-being positively (e.g., happy, enjoyed life, calm, and peaceful) or negatively (e.g., depressed, lonely, bored) during the week before the study on a 4-point Likert-scale ranging from 1 "none or almost none of the time" to 4 "all or almost all of the time." The internal consistency of the scale was Cronbach's $\alpha=.91$. The sum of the scores on all items constructed the well-being score, and higher scores indicated higher subjective well-being. Confirmatory factor analysis also confirmed one-factor structure of the scale. Results are presented in Appendix.

\section{Social Contact}

This measurement included two items on the levels of contact with friends and family members. Participants stated whether they contacted more (1), less (3), or to the same extent (2) with their friends and family members after the implementation of the COVID-19 measures compared to prior to the measures. Higher scores indicated greater social contact with friends and family members.

\section{Academic Satisfaction}

This measurement consisted of 8 items (e.g., I am satisfied with the way my university/college has implemented protective measures concerning the COVID-19 outbreak). The items were rated on a 5-point Likert scale ranging from 1 "strongly agree" to 5 "strongly disagree." Cronbach's $\alpha$ was .78. Higher scores indicated greater academic satisfaction during COVID-19 period.

\section{COVID-19 Knowledge and Information}

This measurement consisted of 8 items testing participants' knowledge about COVID-19. Each item (e.g., The virus survives for days outside the body in open air) was coded as correct or incorrect and the number of the correct items constituted the COVID-19 knowledge score ranging between 0 and 8 . The measurement also included two items on attitudes toward the government's timely and comprehensive communication of the COVID-19 pandemic. They were rated on a 5-point Likert scale ranging from 1 "strongly disagree" to 5 "strongly agree." 


\section{Procedure}

Ethical approval was acquired from the ethics committee of each university included in the present study. An online invitation including relevant information about the study was sent to all students at the universities participating in the current study. One week later, a second invitation was sent. Invitations were sent through emails, student information systems, in-class messaging systems, or phone messages. Some of the universities announced the study through their social media accounts. Students who were willing to participate were directed to the questionnaire through a link. After completing the consent form, participants filled anonymously the questionnaire inserted into the Qualtrics survey tool. The completion of the questionnaire lasted approximately $10 \mathrm{~min}$.

We aimed to reach a wide range of participants (participants from 9 different universities, 4 education programs, and 8 different education fields) but we could not provide financial incentives to the participants because we did not have any research budget. On the other hand, no incentive was provided to participants at most of the universities. Due to local institutional rules, only 195 participants from one university and 25 participants from another university were given course credits as an incentive.

\section{Results}

\section{Descriptive Statistics}

The main variables of interest were analyzed with descriptive and correlational techniques. Demographic variables of age, independent variable of social contact, mediator variables of academic satisfaction and COVID-19 knowledge, and the dependent variable of well-being were analyzed with independent samples $t$-tests for gender differences. As shown in Table 4, male and female groups had statistically significant differences in age, academic satisfaction, and well-being scores.

Table 4 Descriptive statistics and gender differences between the variables

\begin{tabular}{|c|c|c|c|c|c|c|c|c|}
\hline & \multicolumn{3}{|l|}{ Male } & \multicolumn{3}{|c|}{ Female } & \multirow[t]{2}{*}{$t$} & \multirow[t]{2}{*}{$d f$} \\
\hline & $n$ & $M$ & $S D$ & $n$ & $M$ & $S D$ & & \\
\hline Age & 2092 & 24.88 & 7.57 & 5231 & 22.94 & 5.26 & $10.75^{* * * *}$ & 2933 \\
\hline Social contact & 2092 & 3.68 & 1.15 & 5231 & 3.66 & 1.14 & 0.62 & 7321 \\
\hline Academic satisfaction & 2048 & 22.16 & 6.30 & 5160 & 21.64 & 6.00 & $3.18^{* *}$ & 3601 \\
\hline COVID-19 knowledge & 2038 & 5.96 & 1.49 & 5140 & 5.92 & 1.35 & 0.972 & 3426 \\
\hline Subjective well-being & 2092 & 35.27 & 8.88 & 5231 & 33.48 & 8.40 & $7.93 * * *$ & 3668 \\
\hline
\end{tabular}

$* * p<.01, * * * p<.001$ 
Table 5 Summary of descriptive statistics for the main variables including means, standard deviations, and correlations

\begin{tabular}{|c|c|c|c|c|c|}
\hline & 1 & 2 & 3 & 4 & 5 \\
\hline 1. Age & - & & & & \\
\hline 2. Social contact & $.070 * * *$ & - & & & \\
\hline 3. Academic satisfaction & $.192 * * *$ & $.045^{* * *}$ & - & & \\
\hline 4. COVID-19 knowledge & $.084 * * *$ & $.083^{* * *}$ & $.033 * *$ & - & \\
\hline 5. Subjective well-being & $.202 * * *$ & $.091 * * *$ & $.417 * * *$ & $.059 * * *$ & - \\
\hline$N$ & 7363 & 7363 & 7248 & 7218 & 7363 \\
\hline Mean & 23.48 & 3.67 & 21.78 & 5.93 & 33.97 \\
\hline$S D$ & 6.07 & 1.14 & 6.09 & 1.39 & 8.58 \\
\hline
\end{tabular}

$* * p<.01, * * * p<.001$

There was no difference between participants who get course credits as an incentive $(n=188)$ and other participants $(n=7175)$ in terms of these variables.

Pearson correlations between age, social contact, academic satisfaction, COVID-19 knowledge, and well-being were calculated. As shown in Table 5, all the variables were positively correlated at statistically significant levels. All the correlations, except the one between well-being and academic satisfaction, were low-level correlations.

\section{Mediation Model}

To test the relationships between social contact, academic satisfaction, COVID-19 knowledge, and well-being, a serial mediation analysis using Model 6 of PROCESS macro (Hayes, 2018) for SPSS was performed by controlling for gender and age. In this model, social contact was the independent variable, well-being was the dependent variable, academic satisfaction and COVID-19 knowledge were the mediator variables, and gender and age were covariates (see Fig. 1). A bootstrap estimation method was used with 5000 bootstrap samples and $95 \%$ confidence intervals.

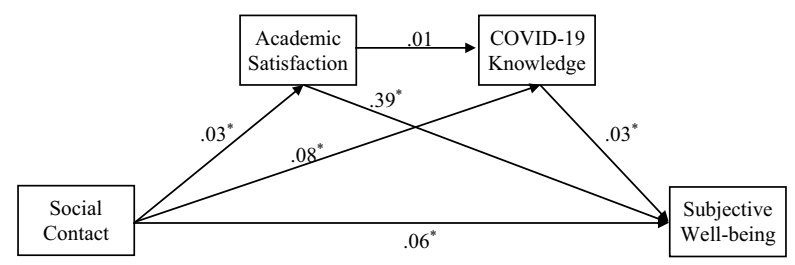

Fig. 1 Serial multiple mediator model predicting subjective well-being. Note. Standardized coefficients are presented. Social contact is the predictor variable, academic satisfaction and COVID-19 knowledge are mediators, subjective well-being is the predicted variable, and gender and age are covariates. The coefficient on association between social contact and subjective well-being presents direct effect of the social contact. $* p<.001$ 
The results showed that there was a significant total effect of social contact on well-being, $B=.59, S E=.09, p<.001,95 \%$ CI $[.42, .76]$. Results also showed that social contact significantly predicted academic satisfaction $(B=.17, S E=.06$, $p<.001,95 \%$ CI $[.04, .29])$ and COVID-19 knowledge $(B=.09, S E=.01, p<$ $.001,95 \%$ CI $[.07, .12])$. However, academic satisfaction did not significantly predict COVID-19 knowledge $(B=.003, S E=.003, p<.001,95 \%$ CI $[-.002, .009])$. In addition, academic satisfaction $(B=.55, S E=.02, p<.001,95 \%$ CI $[.52, .57])$ and COVID-19 knowledge $(B=.18, S E=.07, p<.001,95 \%$ CI $[.06, .31])$ significantly predicted well-being. Furthermore, social contact was significantly related to well-being when controlled for academic satisfaction and COVID-19 knowledge, $B$ $=.48, S E=.08, p<.001,95 \%$ CI $[.33, .64]$. The model explained $4 \%$ variance in academic satisfaction $\left(R^{2}=.04\right), F(4,7213)=72.65, p<.001,1 \%$ variance in COVID-19 knowledge $\left(R^{2}=.013\right), F(5,7212)=20.15, p<.001$ and $20 \%$ of the variance in well-being $\left(R^{2}=.20\right), F(6,7211)=296.50, p<.001$.

Results also revealed that academic satisfaction $(B=.09, S E=.03,95 \%$ CI $[.02$, $.16])$ and COVID-19 knowledge $(B=.02, S E=.01,95 \%$ CI $[.004, .03])$ mediated the relationship between social contact and well-being separately. However, it was observed that the serial indirect effect of social contact on well-being through both academic satisfaction and COVID-19 knowledge was not significant, $B=.00, S E=$ $.00,95 \%$ CI [-.0001, .0004].

Additionally, indirect effect of social contact through academic satisfaction only was significantly different from that of social contact through academic satisfaction and COVID-19 knowledge $(B=.09, S E=.03,95 \%$ CI $[.02, .16])$, also it was significantly different from social contact through COVID-19 knowledge only $(B=.07$, $S E=.04,95 \%$ CI $[.01, .14])$. Finally, the indirect effect of social contact through COVID-19 knowledge only was significantly different from that of academic satisfaction and COVID-19 knowledge $(B=.02, S E=.01,95 \%$ CI $[.004, .03])$. Namely, indirect effects of social contact through academic satisfaction and through COVID19 knowledge were stronger than social contact through academic satisfaction and COVID-19 knowledge sequentially.

\section{Discussion}

One of the groups that have been dramatically affected by the COVID-19 outbreak is the university students. In many countries, students were suddenly asked to leave their college campus and dormitories and expected to engage in distance learning immediately (Dodd et al., 2021; Evandrou et al., 2021). They have experienced isolation from their peers and faculty members, and changes in their living arrangements, financial resources, and study schedules. Moreover, the pandemic carries uncertainty and unpredictability in the short and long term. It cannot be denied that all these difficulties will have mainly psychological effects as well as socioeconomic and social effects. Along with pandemic-related health stresses such as worry about health and uncertainty about the disease, most of the students also have to adjust to new daily and academic arrangements (Liu et al., 2020). As expected, such sudden 
changes in addition to concerns related to health, economic situation, and education may affect students' subjective well-being negatively (Husky et al., 2020; Odriozola-González et al., 2020). Therefore, it is important to examine the impact of the epidemic, which has changed the lives, lifestyles, and habits of college students in unexpected and deeply shocking ways, many of whom have just emerged from adolescence and have just entered young adulthood. In this study, we investigated the subjective well-being of university students in Turkey and its relation to their demographic conditions as well as their levels of social contact, academic satisfaction, and COVID-19 knowledge.

In terms of demographic factors, the results of the current study showed that female participants have significantly low levels of subjective well-being than their male counterparts. Similar to our findings, previous studies also reported that the COVID-19 outbreak had more subjective impact on women, and women experienced higher levels of depression, anxiety, and stress (Ay et al., 2021; Chen et al., 2020a, b; Karaşar \& Canl1, 2020; Wang et al., 2020). While being a female is considered a risk factor for depression during the COVID-19 pandemic (Hyland et al., 2020), these findings are in line with other studies that suggested that women are more vulnerable to depression for several reasons including differences in personality characteristics (Carrillo, Rojo, \& Staats, 2004) and sociocultural roles (Piccinelli $\&$ Wilkinson, 2000). In line with this, such difference in our results might be related to the caregiving role in families where women may be more involved in providing physical and emotional support to the elderly or children (Xiong et al., 2020).

As another demographic finding, the results of this study showed that female students experienced significantly lower academic satisfaction than males. Calaguas (2011) found that female students have been affected differently from stressors related to classroom, teacher, expectation, and schedule. After the pandemic, universities turned to online education which also affected the way the students interact with teachers, schedules of the courses and exams, classroom arrangements and settings, and expectations from students. Such sudden changes may have an impact on female students' academic satisfaction more negatively than their male counterparts.

Moreover, demographic findings of the current study also revealed that students' residential condition has changed after the pandemic occurred. Many students returned to their family homes and started to live with their parents; the number of students who stayed in student halls or shared accommodation decreased dramatically. Because of the university closures, shifting to online education and working, many families moved back together unexpectedly (Evandrou et al., 2021). In this context, Copp et al. (2017) suggested that returning to the parental home may result in higher levels of depressive symptoms for young adults and they may experience loss of independence. In addition to that, our results showed that the number of students who perceive their financial resources to cover their cost as sufficient has decreased after the COVID-19 outbreak. A recent study found that many students experienced anxiety and worry about their financial resources during the pandemic (Baloran, 2020). Therefore, for further research, we believe it is important to take into consideration the effects of demographic factors such as financial resources, living arrangements, and gender differences in relation to subjective well-being during the COVID-19 pandemic. 
Mediation model of the current study is based on a serial mediation analysis that examines the mediating roles of academic satisfaction and COVID-19 knowledge in the relationship between social contact and student well-being. When the findings of mediation analysis were evaluated, the prediction of academic satisfaction by social contact is compatible with similar studies in the literature which are based on online and computer-mediated education (Gopalan et al., 2019; Jung et al., 2002). Although the relationship of social contact with COVID-19 knowledge has not been directly investigated so far, the studies indicated people had been reaching information about COVID-19 through online platforms (Ko et al., 2020; Wang \& Zhao, 2020). In this way, they are connected to other people around the world and collected information about topics that they are interested in, including COVID-19, which in turn can provide social contact and indirect support.

Results of the current study also indicated that the relationship between social contact and well-being was mediated by academic satisfaction. One possible explanation behind this finding might be the dramatic change in the social lives of university students during the pandemic period (Durak et al., 2020; Ertuğ, 2020). Losing social relations and support from the environment caused stress and anxiety, along with the changes in the academic system, which was hard for students to adapt to (Dodd et al., 2021; Son et al., 2020). In addition, these resources, which are more accessible in face-to-face education, may have been perceived as inaccessible with the lockdown. It is among the observations of the authors of this paper that the students refrained from contacting their instructors or professors via e-mail or social media during this period due to an expectation of not getting a response.

A significant finding in the mediation model showed that the relationship between social contact and well-being was mediated by the level of COVID-19 knowledge. During the pandemic, social relations are mostly carried out through online communication, information about COVID-19 is usually gathered from social media platforms (Wang \& Zhao, 2020), and information obtained online is negatively associated with well-being (Lades et al., 2020). Based on our findings, it can be thought that social contact with family and friends, which can be perceived as more reliable sources, may cause positive well-being by affecting the information process about COVID-19. In addition to these, the serial mediation model between social contact and well-being through academic satisfaction and COVID-19 knowledge was not found to be significant. Statistically, academic satisfaction did not predict COVID19 knowledge in the model. A possible explanation of this result could be that the term academic satisfaction in this study also involves students' satisfaction with universities' policy regarding the pandemic and information that is provided by universities in terms of their plans for the future and new arrangements throughout the outbreak. Although the students perceive that they receive insufficient knowledge from the universities, they may still achieve COVID-19-related information from the government's declarations as well as other Internet platforms.

The current study is important in terms of investigating the possible effects of the pandemic on university students. The effect of social contact, which especially decreased and changed during the pandemic period, on the well-being of students was revealed for the first time in a Turkish sample by considering the underlying mechanisms of academic satisfaction and COVID-19 knowledge 
through this study. The implication considering the findings of this study is that lack or lessening of social contact COVID-19 is related with the well-being of students caused by the changes in the academic structure and the system. This information is crucial that points to what is important and what needs to be done to ensure students' well-being in the future. The universities can establish new social support channels through the university to make a positive contribution to students' well-being. Universities should present clear and concrete information for emergencies to their students by using all announcement channels and make easy-access online counseling and health services as well as social support units available. In this way, students may perceive the academic system (including administrative and academic staff) as accessible, and their academic satisfaction may increase when adapting to the new online system. Another psychosocial implication is that universities and policymakers could also take into consideration that due to the pandemic, the living arrangements and economic status of the university students have changed. Therefore, we suggest that such institutions could support students by increasing the availability of funding options for students who are struggling financially.

Considering the strengths of this study, especially the inclusion of the students from nine different universities and the high number of participants are important for the generalizability of the findings of the study. Moreover, it is a strength to form a homogeneous group in terms of demographic characteristics (e.g., relationship status, study fields) for the external validity of the current study. Another strength of the present study is the inclusion of several mediator variables using mediation analysis and the explanation of more variance by revealing the possible mechanisms that explain the current relationship between social contact and students' well-being during the COVID-19 outbreak.

The current study also has several limitations. First, although mediation analysis can suggest causal links, it is not possible to deduce such a causality due to the cross-sectional design of this study. The second methodological limitation is that the majority of the sample of the current study is women. Future studies that provide female-male numerical equivalence may allow for richer comparisons. The third limitation is related to the social contact variable. Social contact is taken without discriminating between contact with family, friends, and other significant people in a student's life. Besides, the items about social contact do not include the contact with academic staff. Further research can study social contact variables separately and may consider including contact with academic staff in the prediction of academic satisfaction. Fourth and the last limitation is that the current research is one time study in which the data was collected just after the first lockdown. The COVID-19 knowledge alters within time; thus, obtaining the relevant information and knowing that you have the true knowledge is not a stable variable and further studies can design a longitudinal study to observe differences through several time intervals.

In conclusion, despite its limitations, this study was quite comprehensive in terms of its sample and explored how the COVID-19 pandemic affected university students' well-being with special emphasis on effects of social contact, academic satisfaction, and knowledge regarding COVID-19. We found that the 
Table 6 Factor loadings of the subjective well-being scale

\begin{tabular}{|c|c|c|c|c|c|c|}
\hline \multirow[t]{2}{*}{ Factor } & \multirow[t]{2}{*}{ Indicator } & \multirow[t]{2}{*}{ Estimate } & \multirow[t]{2}{*}{$\mathrm{SE}$} & \multicolumn{2}{|c|}{$\begin{array}{l}95 \% \text { confidence } \\
\text { interval }\end{array}$} & \multirow[t]{2}{*}{$\mathrm{Z}$} \\
\hline & & & & Lower & Upper & \\
\hline \multirow[t]{14}{*}{ Subjective well-being } & Felt depressed & 0.736 & 0.00873 & 0.719 & 0.753 & 84.3 \\
\hline & $\begin{array}{l}\text { Felt that everything you did was } \\
\text { an effort }\end{array}$ & 0.356 & 0.01041 & 0.335 & 0.376 & 34.1 \\
\hline & Sleep was restless & 0.728 & 0.01000 & 0.708 & 0.747 & 72.8 \\
\hline & Were happy & -0.442 & 0.00747 & -0.457 & -0.427 & -59.2 \\
\hline & Felt lonely & 0.647 & 0.01053 & 0.627 & 0.668 & 61.5 \\
\hline & Enjoyed life & -0.464 & 0.00934 & -0.483 & -0.446 & -49.7 \\
\hline & Felt sad & 0.676 & 0.00808 & 0.660 & 0.692 & 83.6 \\
\hline & Could not get going & 0.551 & 0.01105 & 0.530 & 0.573 & 49.9 \\
\hline & Were bored & 0.582 & 0.00957 & 0.564 & 0.601 & 60.9 \\
\hline & $\begin{array}{l}\text { Were frustrated with things in } \\
\text { general }\end{array}$ & 0.779 & 0.01014 & 0.759 & 0.799 & 76.8 \\
\hline & Felt anxious & 0.686 & 0.00953 & 0.668 & 0.705 & 72.0 \\
\hline & Felt calm and peaceful & -0.471 & 0.00788 & -0.486 & -0.455 & -59.7 \\
\hline & Lacked companionship & 0.418 & 0.01090 & 0.397 & 0.440 & 38.4 \\
\hline & Isolated from others & 0.609 & 0.01125 & 0.587 & 0.631 & 54.1 \\
\hline
\end{tabular}

Note. All indicators were significantly loaded on the one factor at the $.001 p$-level. Residuals were covariates. Factor variances fixed 1. No differences were observed on significance of loading estimates when scale factor fixed scale first indicator which are depressed.

Table 7 Fit measures of the scale

\begin{tabular}{llllllll}
\hline CFI & TLI & SRMR & RMSEA & $\begin{array}{l}\text { RMSEA 95\% } \\
\text { CI }\end{array}$ & AIC & BIC \\
\cline { 3 - 6 } & & & & & \\
\cline { 4 - 6 } & & & & & \\
\hline 0.91 & 0.88 & 0.047 & 0.09 & 0.91 & 0.096 & 225,226 & 225,604 \\
\hline
\end{tabular}

relationship between social contact and well-being was mediated by academic satisfaction and COVID-19 knowledge, separately.

Moreover, this study provided insight regarding the several demographic changes that university students experienced in their lives because of the current pandemic, including changes in living arrangements and financial resources. We hope that the findings of the current study provide guidance for future researchers, mental health professionals, universities, and policymakers to understand possible factors that may affect university students' well-being, especially in Turkey. 


\section{Appendix}

\section{CFA Results for Subjective Well-being Scale}

Fourteen items were used to measure participants' subjective well-being. Participants rated these items on a 4-point Likert-type scale $(1=$ none or almost none of the time, $4=$ all or almost all of the time). The Cronbach alpha coefficient was .91. Confirmatory factor analysis verified the single factor structure of the scale $\left(\chi^{2}(70)=4596, p<.001 ; \mathrm{CFI}=.91\right.$, RMSEA $=.09,90 \%$ CI $\left.[.091, .096]\right)$, hence having acceptable validity and reliability. Each item was loaded on a factor above the minimum acceptable value. Loadings are presented in Table 6. Other fit indices, on the other hand, are presented in Table 7.

Code Availability Not applicable.

Data availability The data that support the findings of this study are available from the corresponding author, upon reasonable request.

\section{Declarations}

Ethics Approval Ethical approval was acquired from the ethics committee of each university included in the present study. The institutional ethics committee approved the research protocol under the SWH-20-38 application number for international part of the study.

Consent to Participate We obtained written informed consent from all individual participants included in the study.

Conflict of Interest The authors declare no competing interests.

\section{References}

Aboagye, E., Yawson, J. A., \& Appiah, K. N. (2020). COVID-19 and e-learning: The challenges of students in tertiary institutions. Social Education Research, 2(1), 1-8. https://doi.org/10.37256/ser. 212021422

Adnan, M., \& Anwar, K. (2020). Online learning amid the COVID-19 pandemic: Students' perspectives. Journal of Pedagogical Sociology and Psychology, 2(1), 2-8. https://doi.org/10.33902/JPSP.20202 61309

Akdeniz, G., Kavakçı, M., Gözügök, M., Yalçınkaya, S., Küçükay, A., \& Sahutoğulları, B. (2020). A survey of attitudes, anxiety status, and protective behaviors of the university students during the COVID-19 outbreak in Turkey. Frontiers in Psychiatry, 11, 695. https://doi.org/10.3389/fpsyt.2020. 00695

Aker, S., \& Midık, Ö. (2020). The views of medical faculty students in Turkey concerning the COVID-19 pandemic. Journal of Community Health, 45, 684-688. https://doi.org/10.1007/s10900-020-00841-9

Arslan, G., Yıldırım, M., Karataş, Z., Kabasakal, Z., \& Kılınç, M. (2020). Meaningful living to promote complete mental health among university students in the context of the COVID-19 pandemic. International Journal of Mental Health and Addiction, 1-13. https://doi.org/10.1007/ s11469-020-00416-8

Arthaud-Day, M. L., Rode, J. C., Mooney, C. H., \& Near, J. P. (2005). The subjective well-being construct: A test of its convergent, discriminant, and factorial validity. Social Indicators Research, 74(3), 445-476. https://doi.org/10.1007/s11205-004-8209-6 
Ay, T., Oruç, D., Özdoğru, A. A. (2021). Adaptation and evaluation of COVID-19 related Psychological Distress Scale Turkish form. Death Studies. Advance online publication. https://doi.org/10.1080/ 07481187.2021.1873459

Badri, S. K. Z., \& Yunus, W. M. A. W. M. (2021). The relationship between academic vs. family / personal role conflict and Malaysian students' psychological well-being during COVID-19 lockdown. Journal of Further and Higher Education, 1-13. https://doi.org/10.1080/0309877X.2021.1884210

Baloran, E. T. (2020). Knowledge, attitudes, anxiety, and coping strategies of students during COVID19 pandemic. Journal of Loss and Trauma, 25(8), 635-642. https://doi.org/10.1080/15325024.2020. 1769300

Beaunoyer, E., Dupere, S., \& Guitton, M. J. (2020). COVID-19 and digital inequalities: Reciprocal impacts and mitigation strategies. Computers in Human Behavior Journal, 11, 1-9. https://doi.org/ 10.1016/j.chb.2020.106424

Calaguas, G. M. (2011). College academic stress: Differences along gender lines. Journal of Social and Development Sciences, 1(5), 194-201. https://doi.org/10.22610/jsds.vli5.644

Çam, H. H., Üstüner Top, F., \& Kuzlu Ayyıldız, T. (2021). Impact of the COVID-19 pandemic on mental health and health-related quality of life among university students in Turkey. Current Psychology. https://doi.org/10.1007/s12144-021-01674-y

Carrillo, J. M., Rojo, N., \& Staats, A. W. (2004). Women and vulnerability to depression: Some personality and clinical factors. The Spanish Journal of Psychology, 7(1), 29-39. https://doi.org/10.1017/ s1138741600004728

Chen, B., Sun, J., \& Feng, Y. (2020b). How have COVID-19 isolation policies affected young people's mental health? Evidence from Chinese college students. Frontiers in Psychology, 11. https://doi.org/ 10.3389/fpsyg.2020.01529

Chen, L., \& Yuan, X. (2020). China's ongoing battle against the coronavirus: Why did the lockdown strategy work well? Socio-Ecological Practice Research, 1-6. https://doi.org/10.1007/ s42532-020-00048-1

Chen, R., Liang, S., Peng, Y., Li, X., Chen, J., Tang, S., \& Zhao, J. (2020a). Mental health status and change in living Rhythms among college students in China during the COVID-19 pandemic: A large-scale survey. Journal of Psychosomatic Research, 137, 110219. https://doi.org/10.1016/j.jpsyc hores.2020.110219

Coffman, D. L., \& Gilligan, T. D. (2002). Social support, stress, and self-efficacy: Effects on students' satisfaction. Journal of College Student Retention: Research, Theory \& Practice, 4(1), 53-66. https://doi.org/10.2190/bv7x-f87x-2mxl-2b31

Colwell, R. R. (1996). Global climate and infectious disease: The cholera paradigm. Science, 274(5295), 2025-2031. https://doi.org/10.1126/science.274.5295.2025

Copp, J. E., Giordano, P. C., Longmore, M. A., \& Manning, W. D. (2017). Living with parents and emerging adults' depressive symptoms. Journal of Family Issues, 38(16), 2254-2276. https://doi. org/10.1177/0192513X15617797

Cox, A., \& Brewster, L. (2020). Library support for student mental health and well-being in the UK: Before and during the COVID-19 pandemic. The Journal of Academic Librarianship, 46(6), 102256. https://doi.org/10.1016/j.acalib.2020.102256

Crooker, K. J., \& Near, J. P. (1998). Happiness and satisfaction: Measures of affect and cognition. Social Indicators Research, 44(2), 195-224. https://doi.org/10.1023/A:1006820710885

Dandagi, G. L., \& Byahatti, S. M. (2011). An insight into the swine-influenza A (H1N1) virus infection in humans. Lung India: Official Organ of Indian Chest Society, 28(1), 34-38. https://doi.org/10. 4103/0970-2113.76299

Diener, E. (2009). Introduction-The Science of well-being: Reviews and theoretical articles by Ed Diener. In E. Diener (Ed.), The science of well-being: Social indicators research series 37. Springer. https://doi.org/10.1007/978-90-481-2350-6_1

Diener, E., \& Fujita, F. (1995). Resources, personal strivings, and subjective well-being: A nomothetic and idiographic approach. Journal of Personality and Social Psychology, 68(5), 926-935. https:// doi.org/10.1037/0022-3514.68.5.926

Diener, E., Suh, E., \& Oishi, S. (1997). Recent findings on subjective well-being. Indian Journal of Clinical Psychology, 24(1), 25-41.

Dodd, R. H., Dadaczynski, K., Okan, O., Mccaffery, K. J., \& Pickles, K. (2021). Psychological wellbeing and academic experience of university students in Australia during COVID-19. International Journal of Environmental Research and Public Health, 18(866), 1-12. https://doi.org/10.3390/ijerp h18030866 
Duman, N. (2020). Üniversite öğrencilerinde COVID-19 korkusu ve belirsizliğe tahammülsüzlük. The Journal of Social Science, 4(8), 426-437. https://doi.org/10.30520/tjsosci.748404

Durak, G., Çankaya, S., \& İzmirli, S. (2020). COVID-19 pandemi döneminde Türkiye'deki üniversitelerin uzaktan eğitim sistemlerinin incelenmesi. Necatibey Eğitim Fakültesi Elektronik Fen ve Matematik Ĕ̆itimi Dergisi, 14(1), 787-809. https://doi.org/10.17522/balikesirnef.743080

Elmer, T., Mepham, K., \& Stadtfeld, C. (2020). Students under lockdown: Comparisons of students' social networks and mental health before and during the COVID-19 crisis in Switzerland. PLOS ONE, 15(7), 1-22. https://doi.org/10.1371/journal.pone.0236337

Ertuğ, C. (2020). Coronavirüs (Covid-19) pandemisi ve pedagojik yansımaları: Türkiye'de açık ve uzaktan eğitim uygulamaları. Açıköğretim Uygulamaları ve Araştırmaları Dergisi, 6(2), 11-53.

Evandrou, M., Falkingham, J., Qin, M., \& Vlachantoni, A. (2021). Changing living arrangements and stress During COVID-19 Lockdown: Evidence from four birth cohorts in the UK. SSM - Population Health, 13, 100761. https://doi.org/10.1016/j.ssmph.2021.100761

Fawaz, M., \& Samaha, A. (2021). E-learning: Depression, anxiety, and stress symptomatology among Lebanese university students during COVID-19 quarantine. Nursing Forum, 56, 52-57. https://doi. org/10.1111/nuf.12521

Franzen, J., Jermann, F., Ghisletta, P., Rudaz, S., Bondolfi, G., \& Tran, N. T. (2021). Psychological distress and well-being among students of health disciplines: The importance of academic satisfaction. International Journal of Environmental Research and Public Health, 18(4), 2151. https://doi.org/10.3390/ijerph18042151

Gassman-Pines, A., Ananat, E. O., \& Fitz-Henley, J. (2020). COVID-19 and parent-child psychological well-being. Pediatrics, 146(4), e2020007294. https://doi.org/10.1542/peds.2020-007294

Gençöz, T., Özlale, Y., \& Lennon, R. (2004). Direct and indirect effects of social support on psychological well-being. Social Behavior and Personality: An International Journal, 32(5), 449-458. https://doi.org/10.2224/sbp.2004.32.5.449

Gopalan, N., Beutell, N. J., \& Middlemiss, W. (2019). International students' academic satisfaction and turnover intentions. Quality Assurance in Education, 27(4), 533-548. https://doi.org/10. 1108/QAE-01-2019-0001

Graupensperger, S., Benson, A. J., Kilmer, J. R., \& Evans, M. B. (2020). Social (Un)distancing: Teammate interactions, athletic identity, and mental health of student-athletes during the COVID-19 pandemic. Journal of Adolescent Health, 67(5), 662-670. https://doi.org/10.1016/j.jadohealth. 2020.08.001

Gunawardena, C. N., \& Zittle, F. J. (1997). Social presence as a predictor of satisfaction within a computer-mediated conferencing environment. American Journal of Distance Education, 11(3), 8-26. https://doi.org/10.1080/08923649709526970

Hagedorn, R. L., Wattick, R. A., \& Olfert, M. D. (2021). "My entire world stopped”: College students' psychosocial and academic frustrations during the COVID-19 pandemic. Applied Research in Quality of Life, 1-22. https://doi.org/10.1007/s11482-021-09948-0

Hassan, S. N., Algahtani, F. D., Zrieq, R., Aldhmadi, B. K., Atta, A., Obeidat, R. M., \& Kadri, A. (2021). Academic self-perception and course satisfaction among university students taking virtual classes during the COVID-19 pandemic in the Kingdom of Saudi-Arabia (KSA). Education Sciences, 11(3), 134. https://doi.org/10.3390/educsci11030134

Hayes, A. F. (2018). Introduction to mediation, moderation, and conditional process analysis: A regression-based approach. Guilford Press.

Horley, J., \& Little, B. R. (1985). Affective and cognitive components of global subjective well-being measures. Social Indicators Research, 17(2), 189-197. https://doi.org/10.1007/BF00302421

Husky, M. M., Kovess-Masfety, V., \& Swendsen, J. D. (2020). Stress and anxiety among university students in France during COVID-19 mandatory confinement. Comprehensive Psychiatry, 102, 152-191. https://doi.org/10.1016/j.comppsych.2020.152191

Hyland, P., Shevlin, M., McBride, O., Murphy, J., Karatzias, T., Bentall, R., Martinez, A., \& Vallières, F. (2020). Anxiety and depression in the Republic of Ireland during the COVID-19 pandemic. Acta Psychiatrica Scandinavica, 142(3), 249-256. https://doi.org/10.1111/acps.13219

Islam, M. A., Barna, S. D., Raihan, H., Khan, M. N. A., \& Hossain, M. T. (2020). Depression and anxiety among university students during the COVID-19 pandemic in Bangladesh: A web-based cross-sectional survey. PLoS ONE, 15(8), e0238162. https://doi.org/10.1371/journal.pone.02381 62 
Jan, S. K. (2015). The relationships between academic self-efficacy, computer self-efficacy, prior experience, and satisfaction with online learning. American Journal of Distance Education, 29(1), 30-40. https://doi.org/10.1080/08923647.2015.994366

Jung, I., Choi, S., Lim, C., \& Leem, J. (2002). Effects of different types of interaction on learning achievement, satisfaction and participation in web-based instruction. Innovations in Education and Teaching International, 39(2), 153-162. https://doi.org/10.1080/14703290252934603

Kanuka, H., \& Anderson, T. (1998). Online social interchange, discord, and knowledge construction. Journal of Distance Education, 13(1), 57-74.

Karaşar, B., \& Canlı, D. (2020). Psychological resilience and depression during the COVID-19 pandemic in Turkey. Psychiatria Danubina, 32(2), 273-279. https://doi.org/10.24869/psyd.2020.273

Ko, N.-Y., Lu, W.-H., Chen, Y.-L., Li, D.-J., Wang, P.-W., Hsu, S.-T., Chen, C.-C., Lin, Y.-H., Chang, Y.-P., \& Yen, C.-F. (2020). COVID-19-related information sources and psychological wellbeing: An online survey study in Taiwan. Brain, Behavior, and Immunity, 87, 153-154. https:// doi.org/10.1016/j.bbi.2020.05.019

Lades, L. K., Laffan, K., Daly, M., \& Delaney, L. (2020). Daily emotional well-being during the COVID-19 pandemic. British Journal of Health Psychology, 25(4), 902-911. https://doi.org/10. 1111/bjhp. 12450

Li, H., Hafeez, H., \& Zaheer, M. A. (2021). COVID-19 and pretentious psychological well-being of students: A threat to educational sustainability. Frontiers in Psychology, 11, 1-8. https://doi.org/10. 3389/fpsyg.2020.628003

Liu, C. H., Pinder-Amaker, S., Hahm, H., \& Chen, J. A. (2020). Priorities for addressing the impact of the COVID-19 pandemic on college student mental health. Journal of American College Health, 1-3. https://doi.org/10.1080/07448481.2020.1803882

Marco, P., \& Wilkinson, G. (2000). Gender differences in depression: Critical review. The British Journal of Psychiatry, 177(6), 486-492. https://doi.org/10.1192/bjp.177.6.486

Metler, S. J., \& Busseri, M. A. (2017). Further evaluation of the tripartite structure of subjective wellbeing: Evidence from longitudinal and experimental studies. Journal of Personality, 85(2), 192206. https://doi.org/10.1111/jopy.12233

Neerinckx, S., Bertherat, E., \& Leirs, H. (2010). Human plague occurrences in Africa: An overview from 1877 to 2008. Transactions of the Royal Society of Tropical Medicine and Hygiene, 104(2), 97-103. https://doi.org/10.1016/j.trstmh.2009.07.028

Odriozola-González, P., Planchuelo-Gómez, Á., Irurtia, M. J., \& de Luis-García, R. (2020). Psychological effects of the COVID-19 outbreak and lockdown among students and workers of a Spanish university. Psychiatry Research, 290, 113108. https://doi.org/10.1016/j.psychres.2020.113108

Oppedal, B., Özer, S., \& Şirin, S. R. (2018). Traumatic events, social support and depression: Syrian refugee children in Turkish camps. Vulnerable Children and Youth Studies, 13(1), 46-59. https://doi. org/10.1080/17450128.2017.1372653

Orben, A., \& Przybylski, A. K. (2019). The association between adolescent well-being and digital technology use. Nature Human Behaviour, 3(2), 173-182. https://doi.org/10.1038/s41562-018-0506-1

Padrón, I., Fraga, I., Vieitez, L., Montes, C., \& Romero, E. (2021). A study on the psychological wound of COVID-19 in university students. Frontiers in Psychology, 12, 1-15. https://doi.org/10.3389/ fpsyg.2021.589927

Piccinelli, M., \& Wilkinson, F. (2000). Gender differences in depression: Critical review. British Journal of Psychiatry, 177, 486-492. https://doi.org/10.1192/bjp.177.6.486

Saltzman, L. Y., Hansel, T. C., \& Bordnick, P. S. (2020). Loneliness, isolation, and social support factors in post-COVID-19 mental health. Psychological Trauma: Theory, Research, Practice, and Policy, 12(1), 55-57. https://doi.org/10.1037/tra0000703

Savage, M. J., James, R., Magistro, D., Donaldson, J., Healy, L. C., Nevill, M., \& Hennis, P. J. (2020). Mental health and movement behaviour during the COVID-19 pandemic in UK university students: Prospective cohort study. Mental Health and Physical Activity, 19, 100357. https://doi.org/10. 1016/j.mhpa.2020.100357

Shek, D. T. (2021). COVID-19 and quality of life: Twelve reflections. Applied Research in Quality of Life, 16(1), 1-11. https://doi.org/10.1007/2Fs11482-020-09898-z

Sifat, R. I. (2020). COVID-19 pandemic: Mental stress, depression, anxiety among the university students in Bangladesh [Letter to the editor]. International Journal of Social Psychiatry, 1-2. https:// doi.org/10.1177\%2F0020764020965995 
Sim, T. N., \& Lui, Z. J. (2020). Positive affect, self-efficacy, goal-related variables, and life satisfaction: The role of goal attainment and domain value. Applied Research in Quality of Life, 1-13. https://doi. org/10.1007/s11482-020-09873-8

Son, C., Hegde, S., Smith, A., Wang, X., \& Sasangohar, F. (2020). Effects of COVID-19 on college students' mental health in the United States: Interview survey study. Journal of Medical Internet Research, 22(9), 1-14. https://doi.org/10.2196/21279

Stenseth, N. C., Atshabar, B. B., Begon, M., Belmain, S. R., Bertherat, E., Carniel, E., Kenneth, L. G., Hedwig, L., \& Rahalison, L. (2008). Plague: Past, present, and future. PLoS Medicine, 5(1), e3. https://doi.org/10.1371/journal.pmed.0050003

The Healthy Minds Network, \& American College Health Association. (2020). The impact of COVID19 on college student well-being. Retrieved from https://www.acha.org/documents/ncha/Healthy_ Minds_NCHA_COVID_Survey_Report_FINAL.pdf

Tomyn, A. J. (2019). 2019 Mental wellbeing survey of prospective international and overseas students. Bupa.https://doi.org/10.13140/RG.2.2.34471.50084

Tran, N. T., Franzen, J., Jermann, F., Rudaz, S., Bondolfi, G., \& Ghisletta, P. (2021). Psychological distress and well-being among students of health disciplines: The importance of academic satisfaction in the context of academic year-end and COVID-19 stress. Preprints, 2021030423. 10.20944/preprints202103.0423.v1

Van de Velde, S., Buffel, V., Bracke, P., Van Hal, G., Somogyi, N. M., Willems, B., Wouters, E., \& for the C19 ISWS Consortium. (2021). The COVID-19 international student well-being study. Scandinavian Journal of Public Health, 49, 114-122. https://doi.org/10.1177/1403494820981186

Villani, L., Pastorino, R., Molinari, E., Anelli, F., Ricciardi, W., Graffigna, G., \& Boccia, S. (2021). Impact of the COVID-19 pandemic on psychological well-being of students in an Italian university: A web-based cross-sectional survey. Globalization and Health, 17(39), 1-14. https://doi.org/ 10.1186/s12992-021-00680-w

Wan Mohd Yunus, W., Badri, S., Panatik, S. A., \& Mukhtar, F. (2021). The unprecedented movement control order (lockdown) and factors associated with the negative emotional symptoms, happiness, and work-life balance of Malaysian university students during the coronavirus disease (COVID-19) Pandemic. Frontiers in Psychiatry, 11, 566221. https://doi.org/10.3389/fpsyt.2020.566221

Wanberg, C. R., Csillag, B., Douglass, R. P., Zhou, L., \& Pollard, M. S. (2020). Socioeconomic status and well-being during COVID-19: A resource-based examination. Journal of Applied Psychology, 105(12), 1382-1396. https://doi.org/10.1037/apl0000831

Wang, C., \& Zhao, H. (2020). The impact of COVID-19 on anxiety in Chinese university students. Frontiers in Psychology, 11(1168), 1-8. https://doi.org/10.3389/fpsyg.2020.01168

Wang, C., Pan, R., Wan, X., Tan, Y., Xu, L., Ho, C. S., \& Ho, R. C. (2020). Immediate psychological responses and associated factors during the initial stage of the 2019 coronavirus disease (COVID19) epidemic among the general population in China. International Journal of Environmental Research and Public Health, 17(5), 1729. https://doi.org/10.3390/ijerph17051729

Wang, Y., McKee, M., Torbica, A., \& Stuckler, D. (2019). Systematic literature review on the spread of health-related misinformation on social media. Social Science \& Medicine, 240(January), 112552. https://doi.org/10.1016/j.socscimed.2019.112552

Wang, Z., \& Xu, J. (2017). Association between resilience and quality of life in Wenchuan Earthquake Shidu parents: The mediating role of social support. Community Mental Health Journal, 53(7), 859-863. https://doi.org/10.1007/s10597-017-0099-6

World Health Organization (2020). COVID-19 weekly epidemiological update, retrieved from https:// www.who.int/emergencies/diseases/novel-coronavirus-2019/situation-reports

Xiong, J., Lipsitz, O., Nasri, F., Lui, L. M. W., Gill, H., Phan, L., Chen-Li, D., Iacobucci, M., Ho, R., Majeed, A., \& McIntyre, R. S. (2020). Impact of COVID-19 pandemic on mental health in the general population: A systematic review. Journal of Affective Disorders, 277, 55-64. https://doi.org/10. 1016/j.jad.2020.08.001

Ye, Z., Yang, X., Zeng, C., Wang, Y., Shen, Z., Li, X., \& Lin, D. (2020). Resilience, social support, and coping as mediators between COVID-19-related stressful experiences and acute stress disorder among college students in China. Applied Psychology: Health and Well-Being, 12(4), 1074-1094. https://doi.org/10.1111/aphw.12211

Yehudai, M., Bender, S., Gritsenko, V., Konstantinov, V., Reznik, A., \& Isralowitz, R. (2020). COVID19 fear, mental health, and substance misuse conditions among university social work students in Israel and Russia. International Journal of Mental Health and Addiction. https://doi.org/10.1007/ s11469-020-00360-7 
Publisher's Note Springer Nature remains neutral with regard to jurisdictional claims in published maps and institutional affiliations.

\section{Authors and Affiliations}

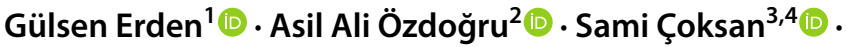

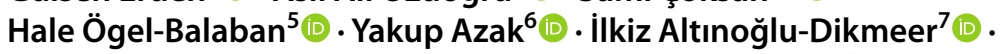 Aysun Ergül-Topçu ${ }^{7}$ (1) - Yeşim Yasak ${ }^{7}$ (1) - Gözde Kıral-Uçar ${ }^{8}$ (D) - Seda Oktay ${ }^{1}$ (D) Pelin Karaca-Dinç ${ }^{1}$ (D) Ezgi Didem Merdan-Yıldız ${ }^{1}$. Selen Eltan ${ }^{3}$ (D) Güler Beril Kumpasoğlu ${ }^{3}$ (i) . Gülsen Baytemir ${ }^{9}$}

Gülsen Erden

erdeng@ankara.edu.tr

Asil Ali Özdoğru

asil.ozdogru@uskudar.edu.tr

Hale Ögel-Balaban

hale.ogelbalaban@eas.bau.edu.tr

Yakup Azak

yakup.azak@istanbul.edu.tr

İlkiz Altınoğlu-Dikmeer

idikmeer@karatekin.edu.tr

Aysun Ergül-Topçu

aysunergultopcu@karatekin.edu.tr

Yeşim Yasak

yesimyasak@karatekin.edu.tr

Gözde Kıral-Uçar

gozdekiral@comu.edu.tr

Seda Oktay

sedaoktyy@gmail.com

Pelin Karaca-Dinç

pelinkaraca35@gmail.com

Ezgi Didem Merdan-Yıldız

ezgi.ddm@gmail.com

Selen Eltan

seltan@metu.edu.tr

Güler Beril Kumpasoğlu

berilk@metu.edu.tr

Gülsen Baytemir

gulsenbaytemir@maltepe.edu.tr

1 Department of Psychology, Ankara University, Ankara, Turkey

2 Department of Psychology, Üsküdar University, İstanbul, Turkey

3 Department of Psychology, Middle East Technical University, Ankara, Turkey

4 Department of Psychology, Erzurum Technical University, Erzurum, Turkey

5 Department of Psychology, Bahçeşehir University, İstanbul, Turkey 
6 Department of Psychology, Istanbul University, İstanbul, Turkey

7 Department of Psychology, Çankırı Karatekin University, Çankırı, Turkey

8 Department of Psychology, Çanakkale Onsekiz Mart University, Çanakkale, Turkey

9 Department of Electrical and Electronics Engineering Department, Maltepe University, İstanbul, Turkey 